\title{
BIOREMEDIATION STUDY: HYDROCARBON DEGRADING BACTERIA
}

\author{
Lies Indah Sutiknowati \\ Research Centre for Oceanography, Indonesian Institute of Sciences \\ Jl. Pasir Putih 1, Ancol Timur, Jakarta - 11048, Indonesia \\ e-mail: lies_indah@yahoo.com.sg
}

\begin{abstract}
Many microorganisms capable of degrading petroleum components have been isolated and few of them seem to be important for petroleum biodegradation in natural environments. To identify the bacteria that play a major role in degradation of petroleum polynuclear aromatic hydrocarbons (PAHs), bacteria were enriched from seawater by using Naphthalene, Phenanthrene, Trichlorodibenzofuran and Benzo[a]pyrene as a carbon and energy source. The result of study that members of the genus Alcanivorax and Thalassospira became predominant in the enrichment cultures. The strains isolated in this study could grow on crude oil and degraded PAH components of crude oil. The number of cells increased to $8.1 \times 10^{6}$ cells $\mathrm{g}^{-1}$ after 14 days in subculture. PAH degradation proceeded parallel with the growth of bacteria cells. This observation which has been conducted in Marine Biotechnology Institute, Kamaishi, Iwate-ken, Japan suggests that Alcanivorax and Thalassospira play an important role in the degradation of petroleum PAHs in marine environment.
\end{abstract}

Keywords: Degrading, PAHs, Bacteria, Enrichment.

\section{INTRODUCTION}

Petroleum which also a crude oil is composed of thousands of components which are separated into saturates, aromatics, resins and asphaltenes. Upon discharged into the sea, crude oil is subjected to weathering, the process caused by the combined effects of physical, chemical and biological modification. Saturates, especially those of smaller molecular weight, are readily biodegraded in marine environments. Aromatics with one, two or three aromatic rings (ex. Naphthalene and Phenanthrene) are also efficiently biodegraded. However, those with four or more aromatic rings are quite resistant to biodegradation (Harayama et al., 1999) such as Trichlorodibenzofuran and Benzo[a]pyrene.

The transport of petroleum across the world is frequent, consequently, the potential for oil spills is significant, and to clean up a spill of hazardous material it must be removed from the area by bioremediation. Bioremediation has the potency to convert hazardous material into innocuous compounds and limited to treating wastes which can be effectively recognized and degraded by microorganisms. Many types of toxic waste are difficult to degrade because of a lack of microorganisms which will recognize and transform the waste.

Research on the fate of petroleum in a marine environment is important to evaluate the environmental threat of oil spills. Microorganisms which have evolved over millions of years have not been exposed to the thousands of man made compounds until relatively recently. Therefore, the bacteria have not had the opportunity to evolve systems to efficiently degrade these waste compounds. Genetically altered organisms could expand the range of compounds and the number of sites at which bioremediation could be used.

Hydrocarbon utilizing microorganisms are ubiquitously distributed in the marine environment following oil spills. These microorganisms naturally biodegrade numerous contaminating petroleum hydrocarbons, thereby cleansing the oceans of oil pollutants. Bioremediation, which is accomplished 
by adding exogenous microbial populations or stimulating indigenous ones, attempts to raise the rates of degradation found naturally to significantly higher rates. Seeding with oil degraders has not been demonstrated to be effective, but addition of nitrogenous fertilizers has been shown to increase rates of petroleum biodegradation (Watanabe, 2001).

This research showed hydrocarbon degrading bacteria which was grown on Phenanthrene, Naphthalene, Trichlorodibenzofuran and Benzo[a]pyrene such as Alcanivorax venustensis and Thalassospira lucentensis. Sample was taken from Beach Simulator Tanks in Marine Biotechnology, Kamaishi, Iwate-ken, Japan in November 2005.

\section{MATERIALS AND METHODS}

Inoculum preparation. The original culture consisted of a mixed consortium isolated from Beach Simulator Tanks in Marine Biotechnology Institute, Kamaishi, Iwate-ken, Japan and grown in the laboratory. Beach Simulator tanks were partially filled with $1 \mathrm{~m}^{3}$ of gravel grains (2-8 mm in diameter) and contained oil pollutant on top of the gravel layer. The culture was isolated by collecting a $0.5-1 \mathrm{~g}$ sample of gravel from the tanks, grown on the shake flasks containing inorganic medium and hydrocarbon compounds. These enrichments were grown for 2 weeks at $20^{\circ} \mathrm{C}$ and checked by observation density every day. To inoculation with fresh 2-weeks culture, each shake flasks was changed as subculture.

Media and culture conditions. The strains were isolated from enrichment cultures and subcultures. The enrichment medium as inorganic medium contained $\left({ }^{-1}\right.$ filtered seawater $): \mathrm{NH}_{4} \mathrm{NO}_{3}$ $1 \mathrm{~g} ; \mathrm{K}_{2} \mathrm{HPO}_{4} 0.2 \mathrm{~g} ; \mathrm{FeC}_{6} \mathrm{H}_{5} \mathrm{O}_{7} \cdot \mathrm{nH}_{2} \mathrm{O} 0.02 \mathrm{~g}$. The $\mathrm{pH}$ was adjusted to 7.6-7.8. For enrichment and for better growth of pure cultures, the growth medium was supplemented with hydrocarbon compounds: Naphthalene, Phenanthrene, Trichlorodibenzofuran, and Benzo [a] pyrene with low (1 ppm) and high (100 ppm) concentration.

Pure cultures were obtained after isolation from agar plate dilution series and incubated at $20{ }^{\circ} \mathrm{C}$. Agar plate containing $\left(1^{-1}\right.$ distilled water $)$ as ONR7a medium: $\mathrm{Na}_{2} \mathrm{SO}_{4} 3.98 \mathrm{~g} ; \mathrm{NaCl} 22.79 \mathrm{~g} ; \mathrm{NH}_{4} \mathrm{Cl}$ $0.27 \mathrm{~g}$; $\mathrm{KCl} 0.72 \mathrm{~g}$; Tapso $1.3 \mathrm{~g}$; Gelrite; $\mathrm{NaBr}$; NaF; $\mathrm{NaHCO}_{3} ; \mathrm{H}_{3} \mathrm{BO}_{3} ; \mathrm{Na}_{2} \mathrm{HPO}_{4} ; \mathrm{MgCl}_{2} \cdot 6 \mathrm{H}_{2} \mathrm{O} 55.9 \mathrm{~g}$; $\mathrm{CaCl}_{2} .2 \mathrm{H}_{2} \mathrm{O} 7.3 \mathrm{~g} ; \mathrm{SrCl}_{2} 0.5 \mathrm{~g} ; \mathrm{FeCl}_{2} \cdot 4 \mathrm{H}_{2} \mathrm{O}$. Purity of cultures was checked by both microscopic observation and growth tests in agar plate medium supplemented with single hydrocarbon compounds and incubated in $20^{\circ} \mathrm{C}$. Pure cultures were stored in Marine Broth agar and ONR7a agar. Pure cultures in liquid medium were stored in $60 \mathrm{ml}$ screw cap bottles as cultivation for next tests containing single hydrocarbon compounds.

DNA extraction and sequence analysis. DNA was extracted directly from duplicate subcultures as described previously. Bacterial cells in the liquid culture were collected either by centrifugation at $20.000 \mathrm{~g}$ for $10 \mathrm{~min}$. and the $16 \mathrm{~S}$ rDNA was amplified by PCR (Kasai et al., 2002). Partial nucleotide sequences of $16 \mathrm{~S}$ rDNA corresponding to positions 37-1370 of the E.coli rRNA sequence were amplified according to the method of Edwards et al. (1989). The primers used for DNA amplification were U515f and U1492r. The PCR products were purified by spin column chromatography (Qiagen kit) and were sequenced directly. The sequence of the 16S rDNA was determined with a Dye terminator sequencing kit (Applied Biosystems) and the product was analyzed with an ABI-Prism DNA sequencer (Applied Biosystems). The sequence was aligned and the alignment was completed manually. The resulting alignment of 977 nucleotides was used for Phylogenetic analyses. Sequence identification was performed by use of the BLASTN facility of the NCBI and the Sequence Match facility of the Ribosomal Database Project.

Denaturing Gradient Gel Electrophoresis and sequence analysis. PCR amplification of the 16S rDNA fragments prior to DGGE was performed as described by Muyzer et al. (1993). The electrophoresis takes place in a vertically placed polyacrylamide gel in a gradient of denaturants. Denaturants was contained (in $1 \mathrm{x}$ TAE buffer): $6.5 \%$ acryl amide, $40 \%$ formamide, $7 \mathrm{M}$ urea and $\mathrm{ddH}_{2} \mathrm{O}$. The primers used for PCR were $341 \mathrm{fGC}$; GC1 or GC2 and 534r. DGGE has been shown to detect differences in the melting behavior of small DNA fragments (200-700 bp) that differ by as little as single base substitution. This method separates DNA fragments of the same lengths on the basis of differences in basepair sequences, and was recently adapted from detection of point mutations, to being used on a mixture of 16S rDNA gene fragments amplified by PCR from complex environmental DNA samples. Each band in a DGGE gel is believed to 
be representing a single species/genus although heterogeneity of rDNA genes within a single species has been reported. The strong DGGE bands were excised with a razor blade and soaked in 1001/41 of TE buffer, and its DNA sequence was determined as described previously (Watanabe $e t$ al., 1998). Purified DNA was sequenced with an $\mathrm{ABI}-P$ rism and the resulting sequences were compared with the compilation of $16 \mathrm{~S}$ rDNA genes available in GenBank nucleotide library by a BLAST search through the NCBI.

Analysis of the oil samples. The oil from liquid and gravel were extracted by hexane, then shaking and removing to other vial containing sodium sulfate. An analysis of the crude oil by gas chromatography-mass spectrometry was performed by using a QP-5000 instrument fitted with a fused silica capillary column. The temperature program gave a $2-\mathrm{min}$ hold at $50^{\circ} \mathrm{C}$, an increase to $300^{\circ} \mathrm{C} / \mathrm{min}$ at $6^{\circ} \mathrm{C} / \mathrm{min}$ and a 16 $\min$ hold at $300^{\circ} \mathrm{C}$. The injection volume was $1 \mu \mathrm{l}$, and the carrier gas was helium $(1.7 \mathrm{ml} / \mathrm{min})$. The mass-selective detector was operated in the scan mode to obtain spectral data for identifying the compounds and in the selected ion monitoring (SIM) mode for quantifying the target compounds. GC/MS was performed according to the method of Wang et al. (1998) and all values obtained by the instrumental analyses were normalized to that of $17 \pm(\mathrm{H}), 21^{2}(\mathrm{H})$-hopane (Prince et al., 1994).

\section{RESULTS AND DISCUSSION}

The gravel which were contaminated by oil and sea water were taken from Beach Simulator tanks; using these samples, four sets of hydrocarbon based cultures, each in duplicate, were prepared. These cultures were incubated at $20^{\circ} \mathrm{C}$ for 2 weeks and changed as subcultures for few times with constant shaking to promote the growth of oil degrading microorganism indigenous to the oil paste and sea water. An increase in cell number was observed when the culture contains high concentration of hydrocarbon compounds (see Table 1).

The bacteria grew on enrichment culture for one month and the cell number of bacteria increased on subculture containing high concentration of hydrocarbon compounds. Trichlorodibenzofuran and Benzo[a]pyrene are resistant compounds to biodegradation but the bacteria can grow rapidly only for 2 weeks. An observation on colonies number of the bacteria was showed an increase on subculture (see Table 2). It means that the bacteria grew on hydrocarbon compounds at low or high concentration.

Table 1. Cell counts after enrichment and subcultures by DAPI

\begin{tabular}{|c|c|c|c|}
\hline Hydrocarbon Source & Enrichment & Subculture 1 & Subculture 2 \\
\hline $1 \mathrm{ppm}$ Naphthalene & $2.1 \times 10^{7}$ & $5.1 \times 10^{6}$ & $1.1 \times 10^{7}$ \\
\hline $100 \mathrm{ppm}$ Naphthalene & $2.2 \times 10^{7}$ & $8.4 \times 10^{7}$ & $2.1 \times 10^{8}$ \\
\hline $1 \mathrm{ppm}$ Phenanthrene & $5.6 \times 10^{6}$ & $1.1 \times 10^{7}$ & $2.5 \times 10^{7}$ \\
\hline $100 \mathrm{ppm}$ Phenanthrene & $1.9 \times 10^{7}$ & $1.1 \times 10^{8}$ & $1.1 \times 10^{8}$ \\
\hline $1 \mathrm{ppm}$ 3Chlorodibenzofuran & $7 \times 10^{6}$ & $2.1 \times 10^{7}$ & $7.9 \times 10^{6}$ \\
\hline $100 \mathrm{ppm}$ 3Chlorodibenzofuran & $1.6 \times 10^{7}$ & $6.8 \times 10^{7}$ & $1.9 \times 10^{7}$ \\
\hline $1 \mathrm{ppm}$ Benzo[a]pyrene & $1.5 \times 10^{7}$ & $7.1 \times 10^{6}$ & $1.1 \times 10^{7}$ \\
\hline $100 \mathrm{ppm}$ Benzo[a]pyrene & $2.6 \times 10^{7}$ & $2.8 \times 10^{7}$ & $7.1 \times 10^{7}$ \\
\hline
\end{tabular}

Table 2. Colony counts after enrichment and subcultures

\begin{tabular}{|c|c|c|c|}
\hline \multirow{2}{*}{ Hydrocarbon } & \multicolumn{3}{|c|}{ Medium ONR7a (CFU/ml) } \\
\cline { 2 - 3 } & Enrichment & Subculture 1 & Subculture 2 \\
\hline $1 \mathrm{ppm}$ Naphthalene & $2.6 \times 10^{5}$ & $1.5 \times 10^{4}$ & $3.1 \times 10^{5}$ \\
\hline $100 \mathrm{ppm}$ Naphthalene & $3.3 \times 10^{5}$ & $2.6 \times 10^{6}$ & $8.1 \times 10^{6}$ \\
\hline $1 \mathrm{ppm}$ Phenanthrene & $6.3 \times 10^{4}$ & $2.3 \times 10^{5}$ & $1.8 \times 10^{5}$ \\
\hline $100 \mathrm{ppm}$ Phenanthrene & $1.3 \times 10^{5}$ & $2.7 \times 10^{6}$ & $6.9 \times 10^{6}$ \\
\hline $1 \mathrm{ppm} 3$ Chlorodibenzofuran & $1.6 \times 10^{6}$ & $1.8 \times 10^{5}$ & $4.7 \times 10^{4}$ \\
\hline $100 \mathrm{ppm}$ 3Chlorodibenzofuran & $2.5 \times 10^{5}$ & $1.7 \times 10^{6}$ & $1.7 \times 10^{5}$ \\
\hline $1 \mathrm{ppm}$ Benzo[a]pyrene & $1.8 \times 10^{5}$ & $4 \times 10^{4}$ & $7.3 \times 10^{4}$ \\
\hline $100 \mathrm{ppm}$ Benzo[a]pyrene & $2.1 \times 10^{5}$ & $1.3 \times 10^{6}$ & $1.4 \times 10^{6}$ \\
\hline
\end{tabular}




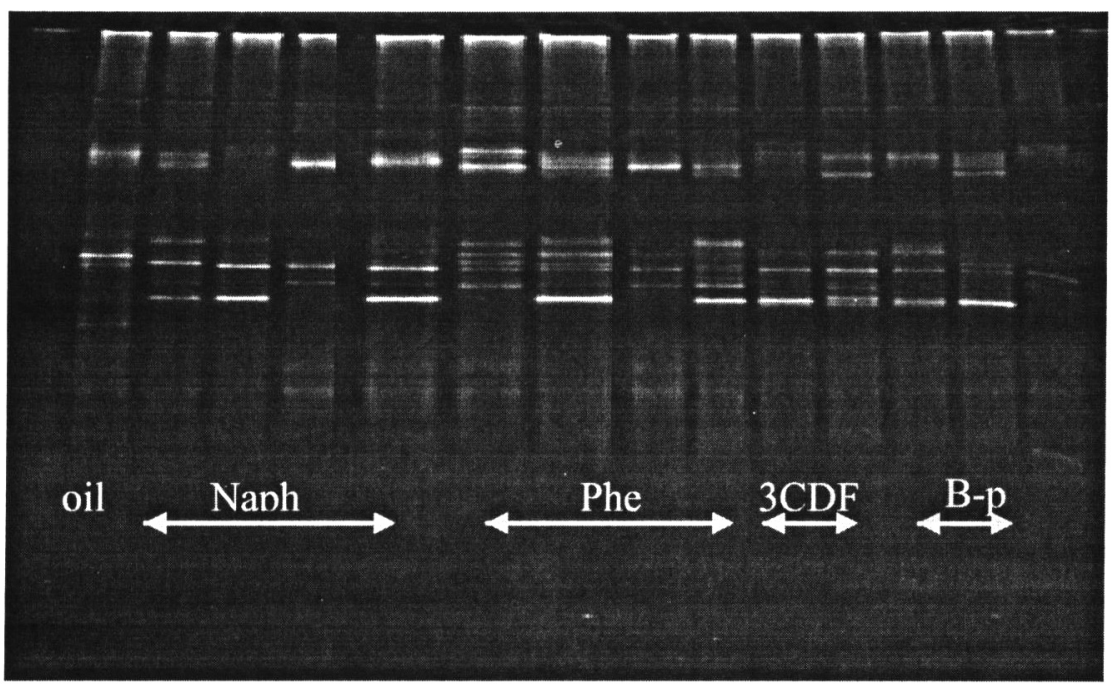

Figure 1. DGGE profiles of partial 16S rDNA fragments showing bacterial populations grown in hydrocarbon cultures. The bacteria grown in seawater was supplemented with oil; Naphthalene; Phenanthrene; Trichlorodibenzofuran; and Dibenzo[a]pyrene compounds. Many bands appeared as community structures when analyzed by PCR-DGGE.

In this study, PCR/DGGE was used to analyze the major members of the bacterial population in culture and subcultures (Fig.1). The PCR/DGGE analysis of $16 \mathrm{~S} \mathrm{rDNA}$ fragments has been applied to detect specific microbial populations and to describe the overall structure of the microbial communities in various environments (Giovannoni et al., 1990).

The bacterial isolates in these pure cultures were then analyzed by PCR amplified 16S rDNA fragments and their DNA sequences were determined. It was found that most of sequence results of strain which grown on all hydrocarbon compounds (Naphthalene, Phenanthrene, Trichlorodibenzofuran, Benzo[a]pyrene) was 92$95 \%$ identical to that of Thalassospira lucentensis; and strain that grew on Phenanthrene was $98 \%$ identical to that of Alcanivorax venustensis (Table 3 ).
Thalassospira lucentensis is a species novel bacterium in the family Rhodospirillaceae. This bacteria isolated under oligothropic conditions, indicated high sequence identity to the well characterized Rhodospirillum rubrum [Aquaspirillum] itersonii and [Oceanospirillum] pusillum microorganisms, which are representatives of the \pm -subclass of the Proteobacteria (LopezLopez, 2002). Phylogenetic tree of many strain and members of family Rhodospirillaceae, as inferred from 16S rDNA sequence, showed in Figure 7. This observation showed that Thalassospira lucentensis can grow on all hydrocarbon compounds with low and high concentration.

Alcanivorax venustensis is a hydrocarbon degrading bacteria related to species Alcanivorax borkumensis. Alcanivorax borkumensis is a bacteria of the ${ }^{3}$-subclass of the Proteobacteria

Table 3. 16S rDNA Gene Sequences of Colony. Most of the colony was Thalassospira lucentensis.

\begin{tabular}{|l|c|c|c|}
\hline \multicolumn{1}{|c|}{$\begin{array}{c}\text { Subculture } \\
\text { ONR7a }\end{array}$} & Closest Relative in The Database & $\begin{array}{c}\% \\
\text { Similarity }\end{array}$ & Number of strain \\
\hline Naphthalene (1 ppm) & Thalassospira lucentensis & 95 & 5 \\
\hline Naphthalene (100 ppm) & Thalassospira lucentensis & 94 & 3 \\
\hline Phenanthrene (100 ppm) & Thalassospira lucentensis & 92 & 3 \\
\hline 3Chlorodibenzofuran (1 ppm) & Alcanivorax venustensis & 98 & 2 \\
\hline 3Chlorodibenzofuran (100 ppm) & Thalassospira lucentensis & 95 & 4 \\
\hline Benzo[a]pyrene (1 ppm) & Thalassospira lucentensis & 95 & 3 \\
\hline Benzo[a]pyrene (100 ppm) & Thalassospira lucentensis & 94 & 3 \\
\hline
\end{tabular}


(Yakimov, 1998). The bacteria belonging to Alcanivorax predominated in sea water containing crude oil or heavy oil; in this observation, we found that Alcanivorax venustensis can grow on high concentration of Phenanthrene.

Morphology of the bacteria. The cells of Thalassospira lucentensis are vibrioid to spiral shaped, $3-5 \mu \mathrm{m}$ long by $0.6 \mu \mathrm{m}$ wide (Fig.2) and move very quickly, being stimulated by air or oxygen. The cells divide by binary fission (Fig. 3), and pairs of cells resembling short spiral are often seen. The cells of Alcanivorax venustensis are rods like and generally shorter $(0.6-11 / 4 \mathrm{~m}$ wide and $0.8-1.51 / 4 \mathrm{~m}$ long) when used hydrocarbon or energy carbon (Fig.4). The cells divide by binary fission also (Fig.5).

Blast search of the complete $16 \mathrm{~S}$ rDNA sequence for strain of hydrocarbon degrading bacteria showed that the isolates have high similarity with a cluster of partially sequenced. It showed the highest level of sequence similarity to a number of characterized bacteria from the \pm -subclass of the Proteobacteria. Our Phylogenetic analysis has included all named representatives of the family Rhodospirillaceae, Oceanospirillum pusillum,
Aquaspirillum itersonii and Rhodospirillum rubrum.

The biodegradation of hydrocarbon compounds was stimulated when fertilizers were supplemented. In those conditions, Thalassospira lucentensis and Alcanivorax venustensis were best hydrocarbons degrading bacteria (on Phenanthrene and Naphthalene) comparing with several bacteria (showed in Fig.7). But growth of that both bacteria on hydrocarbon or heavy oil were not particularly rapid in comparison with other hydrocarbon degrading bacteria.

The isolates of Thalassospira lucentensis have degraded of crude oil, and its components were analyzed by gas chromatography/mass spectrometry (GC/MS). The addition of fertilizers promoted the degradation of certain components of crude oil: about $70 \%$ - more than $90 \%$ of $n$ alkanes and more than $70 \%$ of (alkyl) naphthalene were degraded in 30 days. The degradation of phenanthrene, dibenzothiophenes, fluorene and their alkyl-substituted derivatives) was less extensive, being between $20 \%$ to $50 \%$ (see Table 4). Alcanivorax venustensis also degraded oil, like Alkanivorax berkumensis did as observation by many researchers.

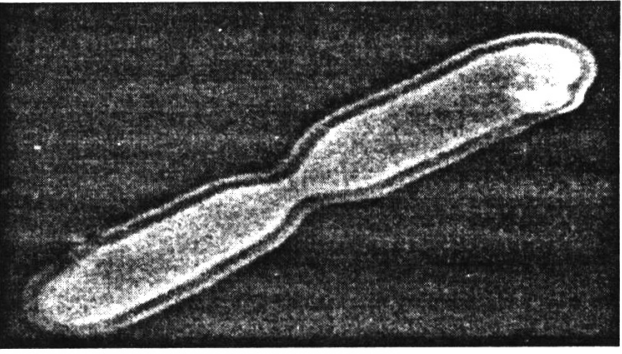

Figure 3. Showing binary fission of
Thalassospira lucentensis.

Figure 3. Showing binary fission of
Thalassospira lucentensis.
Figure 2. Electron microscopy of Thalassospira lucentensis cells.

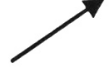

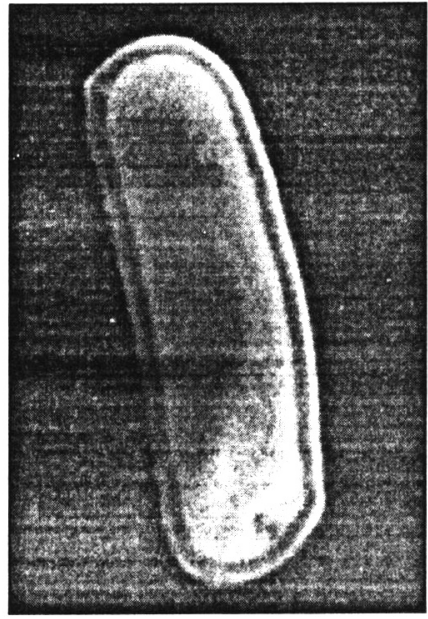

Figure 4. Ultrastructure of Alcanivorax venustensis cells. Exponential phase cells appear as short rods

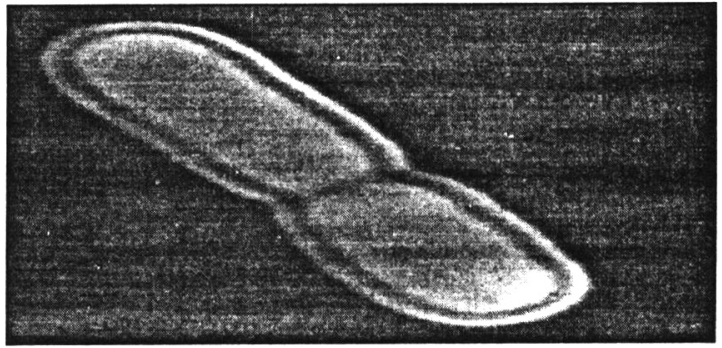

Figure 5. Binary fission of Alcanivorax venustensis, showing typical cytoplasmic granularity 


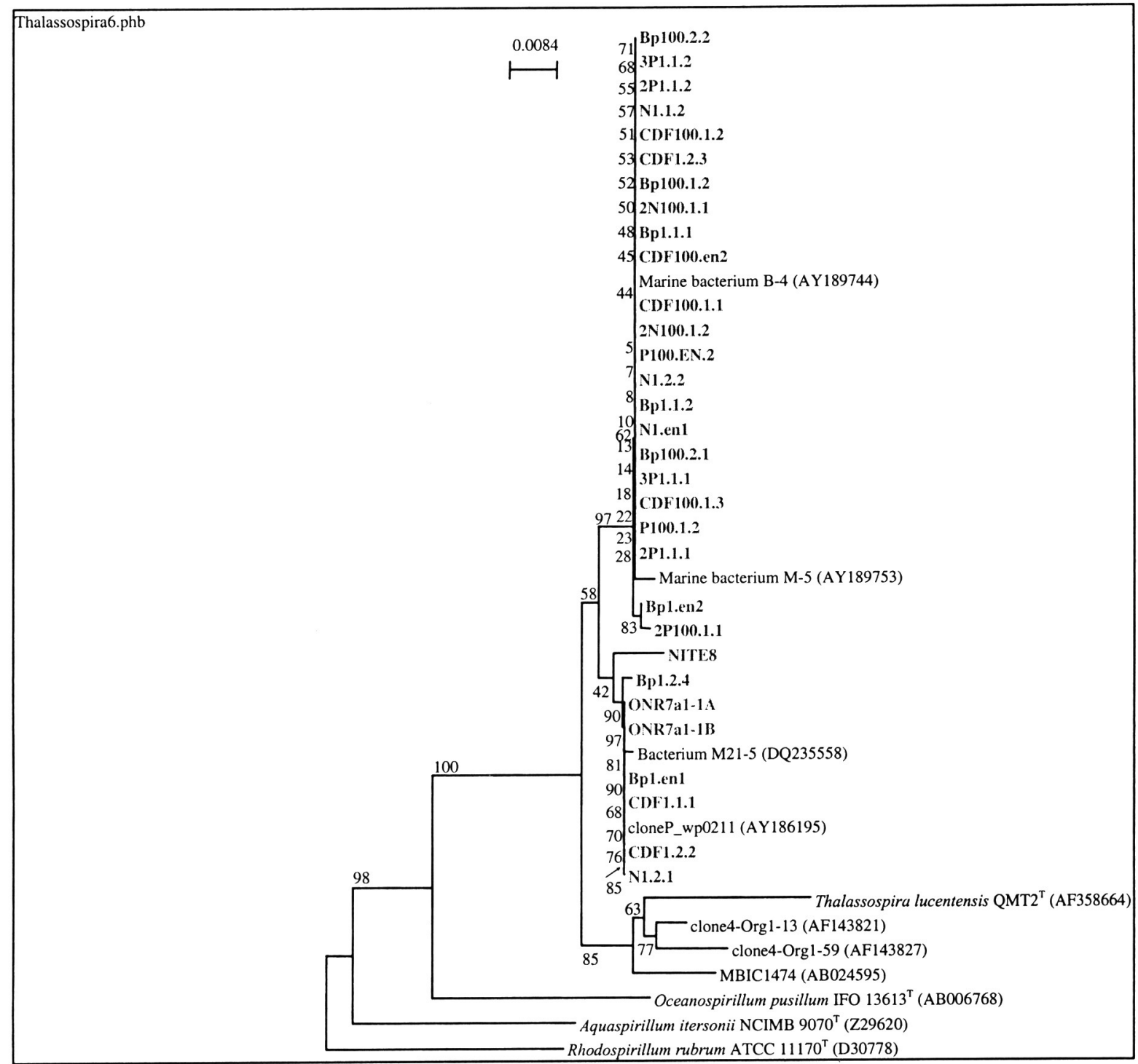

Figure 6. Phylogenetic tree of Thalassospira lucentensis derived from analysis of the $16 \mathrm{~S}$ rDNA gene sequences from strain isolates of hydrocarbon degrading bacteria (Phenanthrene, Naphthalene, Trichlorodibenzofuran and Benzo[a]pyrene)

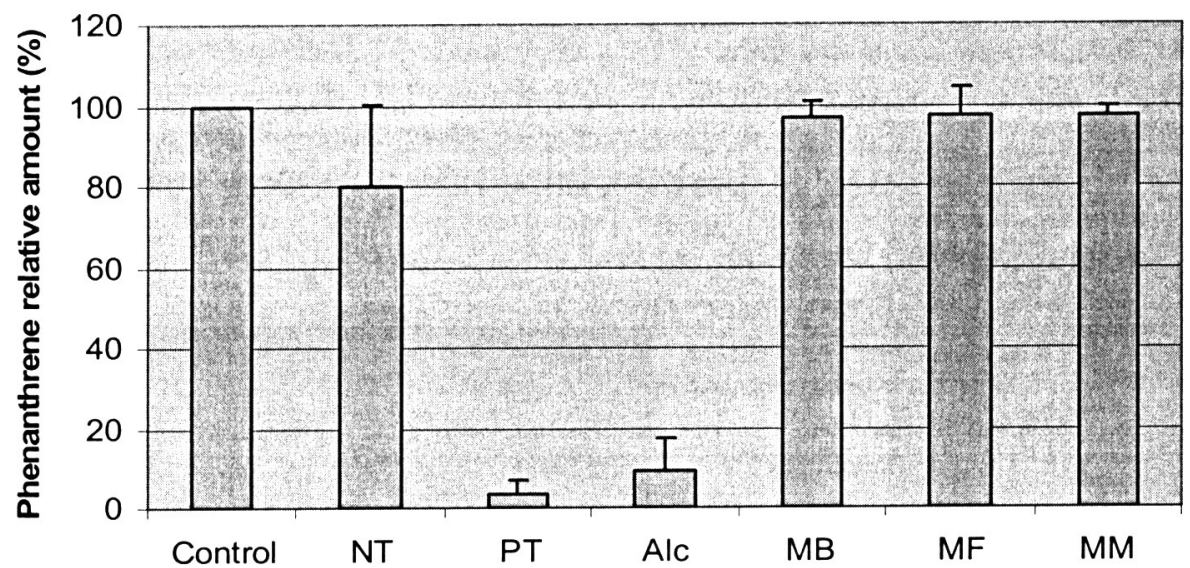

Figure 7. Hydrocarbon degrading bacteria.

NT: Thalassospira lucentensis was degraded Naphthalene.

PT: Thalassospira lucentensis was degraded Phenanthrene.

Alc: Alcanivorax venustensis. MB: Marinobacter bryozoorum.

MF: Marinobacter flavimaris. MM: Martelella mediterania 
Table 4. Biodegradation of GC/MS detectable components of crude oil in batch cultures. The concentrations of oil components were determined, each value is normalized by the concentrations of $17 \pm(\mathrm{H}), 21^{2}(\mathrm{H})$-hopane.

\begin{tabular}{|c|c|c|}
\hline Strain & $\begin{array}{l}\text { Phylogenetically related } \\
\text { sequence }\end{array}$ & Biodegradation \\
\hline 1.8 & Thalassospira Iucentensis & $+\left(\mathrm{C}_{10}, \mathrm{C}_{25-33}\right)$ \\
\hline 3CDF 100.1.1 & Thalassospira lucentensis & $+\left(\mathrm{C}_{29-33)}\right.$ \\
\hline P100.1.2 & Thalassospira Iucentensis & $+\left(\mathrm{C}_{32-33}, \mathrm{Naph}, \mathrm{Phe}, \mathrm{DBT}, \mathrm{Flu}\right)$ \\
\hline 2P100.1.1 & Thalassospira lucentensis & $+\left(\mathrm{C}_{33}\right)$ \\
\hline Bp100.2.2 & Thalassospira Iucentensis & $\pm\left(\mathrm{C}_{24-32, \mathrm{DBT})}\right.$ \\
\hline $3 \mathrm{CDF} 1.2 .2$ & Thalassospira lucentensis & $\pm\left(\mathrm{C}_{26-31}, \mathrm{DBT}, \mathrm{Flu}\right)$ \\
\hline Bp1.2.4 & Thalassospira lucentensis & $\pm\left(\mathrm{C}_{14-32}, \mathrm{DBT}\right)$ \\
\hline
\end{tabular}

Acknowledgements. I am grateful to Ms.Yumiko Kodama and Dr.Kazuya Watanabe for their kind as supervisor. This work is part of training for identification of hydrocarbon degrading bacteria, supported by JICA.

\section{REFERENCES}

Edwards, U., T.Rogall, H.Blocker, M.Emde and E.C.Bottger. 1989. Isolation and direct complete nucleotide determination of entire genes. Characterization of gene coding for $16 \mathrm{~S}$ rRNA. Nucleic Acids Res. 17: 7843-7853.

Giovannoni, S.J, T.B.Britschgi, C.L.Moyer and K.G.Field. 1990. Genetic diversity in Sargasso Sea Bacterioplankton. Nature 345: 60-63.

Harayama, S., H.Kishira, Y.Kasai and K.Shutsubo. 1999. Petroleum Biodegradation in Marine Environments. J. Mol. Microbiol. Biotechnol.1 (1): 63-70.

Kasai, Y., H.Kishira, T.Sasaki, K.Syutsubo, K.Watanabe and S.Harayama. 2002. Predominant Growth of Alcanivorax Strains in Oil Contaminated and Nutrient Supplemented Sea Water. Environmental Microbiology 4(3): 141-147.

Lopez-Lopez, A., M.J.Pujalte, S.Benlloch, M.MataRoig, R.Rosello-Mora, E.Garay and F.RodriguezValera. 2002. Thalassospira lucentensis gen. nov., sp. Nov., a new marine member of the \pmProteobacteria. IJSEM(52): 1277-1283.
Yakimov, M.M, P.N.Golyshin, S.Lang, E.R.B. Moore, W.Abraham, H.Lunsdorf and K.N. Timmis. 1998. Alcanivorax borkumensis gen. nov., sp. Nov., a new, hydrocarbon-degrading and surfactantproducing marine bacterium. IJSB (48): 339-348.

Muyzer, G., E.C.De Waal and A.G.Uitterlinden. 1993. Profiling of complex microbial populations by denaturing gradient gel electrophoresis analysis of polymerase chain reaction-amplified genes coding for 16S rRNA. Appl. Environ Microbiol. 59: 695-700.

Prince, R.C., D.L.Elmendorf, J.R.Lute, C.S.Hsu, C.E.Haith, J.D.Senius. 1994. $17 \pm(\mathrm{H}), 21^{2}(\mathrm{H})$-hopane as a Conserved Internal Marker for Estimating the Biodegradation of Crude Oil. Environ.Sci.Technol. 28: 142-145.

Watanabe, K., S.Yamamoto, S.Hino, and S.Harayama. 1998. Population Dynamics of Phenol-Degrading Bacteria in Activated Sludge Determined by gyrB targeted Quantitative PCR. Appl. Environ. Microbiol. 64: 1203-1209.

Wang, Z., Fingas, M., Blenkinsopp, S., Sergy, G., Landriault, M., Sigouin,L. 1998. Comparison of oil composition changes due to biodegradation and physical weathering in different oils. J. chromatogr. A 809: 89-107.

Watanabe, K. 2001. Microorganisms Relevant to Bioremediation. Current Opinion in Biotechnology 12: 237-241. 